\title{
Anatomy, histochemistry and biochemistry of glucovanillin, oleoresin and mucilage accumulation sites in green mature vanilla pod (Vanilla planifolia; Orchidaceae): a comprehensive and critical reexamination
}

\author{
Eric Odoux, Jean-Marc BRILloueT*
}

CIRAD, Persyst,

UMR Qualisud, TA B-95 / 16,

F-34398 Montpellier Cedex 5, France

brillouet@cirad.fr
* Correspondence and reprints

Received 24 February 2009 Accepted 24 April 2009

Fruits, 2009, vol. 64, p. 221-241 (C) 2009 Cirad/EDP Sciences All rights reserved DOI: $10.1051 /$ fruits/2009017 www.fruits-journal.org RESUMEN ESPAÑOL, p. 241
Anatomy, histochemistry and biochemistry of glucovanillin, oleoresin and mucilage accumulation sites in green mature vanilla pod (Vanilla planifolia; Orchidaceae): a comprehensive and critical re-examination.

Abstract - Introduction. Mature green vanilla pods accumulate 4-O-(3-methoxy-benzaldehyde)- $\beta$-D-glucoside (glucovanillin), which, upon hydrolysis by an endogenous $\beta$-glucosidase, liberates vanillin, the major aroma component of vanilla. Sites of storage of glucovanillin in the pod have been controversially reported for decades; we aim, using precise and widely accepted technical terminology, to clarify this controversy by providing an anatomical, histochemical and biochemical evidence-based picture of glucovanillin accumulation sites. The pod also synthesizes an oleoresin and a mucilage of unknown constitutions; we report here their localization and structures. Materials and methods. The pod anatomy was examined by light and epifluorescence microscopy. A protocol was established allowing fine hand-dissection of diverse anatomical parts of the pod (mesocarp, placentae, trichomes, intralocular interstitial cell-free region and seeds). Glucovanillin and $\gamma$-pyranones were extracted and analyzed by HPLC, while the structures of the mucilaginous polysaccharides were determined after permethylation. Results and discussion. Glucovanillin is essentially stored in the placentae (92\%) and marginally in trichomes (7\%); traces were measured in the mesocarp and intralocular interstitial cellfree medium. Trichomes store massive amounts of a fluorescing oleoresin (44\%) rich in alkenylmethyldihydro- $\gamma$-pyranones and synthesize a mucilage made of a glucomannan and a pectic polysaccharide carrying monomeric arabinose and galactose side-chains. Conclusion. To date, the physiological roles of glucovanillin, long-chain pyranones, and mucilage remain unknown.

France / Vanilla planifolia / Orchidaceae / vanilla / trichomes / vanillin / oleoresins / fluorescence / mucilages / polysaccharides

Anatomie, histochimie, et biochimie des sites d'accumulation de la glucovanilline, d'une oléoresine, et d'un mucilage dans la gousse de vanille verte mature (Vanilla planifolia ; Orchidaceae) : ré-examen critique d'ensemble.

Résumé - Introduction. Les gousses de vanille vertes matures accumulent du 4-O-(3méthoxy-benzaldehyde)- $\beta$-D-glucoside (glucovanilline), qui, par hydrolyse à l'aide une $\beta$-glucosidase endogène, libère de la vanilline, le composé d'arôme majoritaire de la vanille. Les sites de stockage de la glucovanilline dans la gousse ont été mentionnés depuis des décades de façon controversée; en utilisant une terminologie technique précise et largement acceptée, nous nous proposons de clarifier cette controverse en présentant un tableau, fondé sur des preuves anatomiques, histochimiques et biochimiques, des sites d'accumulation de la glucovanilline. La gousse synthétise aussi une oléorésine et un mucilage de compositions inconnues ; nous donnons ici leurs localisations et structures. Matériel et méthodes. L'anatomie de la gousse a été examinée en microscopies photonique et d'épifluorescence. Un protocole a été mis au point qui permet une dissection manuelle fine des différentes parties anatomiques de la gousse (mésocarpe, placentae, trichomes, zone acellulaire interstitielle du locule et graines). La glucovanilline et les $\gamma$-pyranones ont été extraites et analysées par HPLC tandis que les structures des polysaccharides du mucilage ont été déterminées par perméthylation. Resultats et discussion. La glucovanilline est stockée essentiellement dans les placentae (92\%) et marginalement dans les trichomes (7\%); des traces ont été détectées dans le mésocarpe et le milieu acellulaire interstitiel du locule. Les trichomes accumulent des quantités massives d'une oléorésine fluorescente ( $44 \%$ ) et riche en alkenylmethyldihydro- $\gamma$-pyranones et ils synthétisent un mucilage constitué d'un glucomannane et d'un polysaccharide pectique portant des chaînes latérales monomériques d'arabinose et de galactose. Conclusion. Jusqu'à ce jour les rôles physiologiques de la glucovanilline, des pyranones à longues chaînes, et du mucilage demeurent inconnus.

France / Vanilla planifolia / Orchidaceae / vanille / trichome / vanilline / oléorésine / fluorescence / mucilage / polyoside 


\section{Introduction}

Amongst orchids, monocotyledonous plants from the Orchidaceae family, a new subfamily, Vanilloideae, to which belongs the common vanilla (Vanilla planifolia Jackson ex Andrews, Vanilleae tribe), was recently recognized through molecular taxonomy [1]. Within Vanilloideae (15 genera containing 200 species), the genus Vanilla comprises 110 species $[2,3]$ of which only three are cultivated, namely, $V$.planifolia, $V$. tabitensis and $V$.pompona [4]. The term "vanilla" is used for both the plant and its fruit.

Vanilla, a monopodial climbing vine, bears epigynous flowers. The syncarpous gynoecium constitutes a stigma, a style and an inferior tricarpellate unilocular ovary bearing placentae, from which rows of numerous anatropous ovules differentiate only after pollination [5]. The fleshy fruits of vanilla vine, improperly called vanilla beans, develop from the inferior ovary into elongated pod-like berries with a trigone cross-section [6]; when fruits reach maturity, pods open longitudinally from the apical end by two dehiscence splits, then progressively dry, in the end turning into a capsule [7]. Each carpel shows from the outside a sectioned vanilla pod (partia view). thin cutinized epicarp with thick-walled cells, a fleshy chlorophyllous mesocarp bearing itself two parietal placental bilobed laminae (or ridges) running the fruit length, each lamina being subdivided into two lobes symmetrically bent towards the interlamina area from one side and one of the three trigone angles to the other side [8] (figures 1-3). Lobes bear myriads of very small crustose seeds [6]. In between the placental ridges, differentiated from the innermost endocarpic layer after fertilization has occurred, lie faint yellowish strips of much elongated hair-like tubular cells, the trichomes (or papillae, or hairs) [5, 8-11]; these cells synthesize and excrete in between themselves and into the locular space a viscous mucilage embedding seeds, also called a matrix [11], the nature of which is unknown, and expel oleoresin droplets when perturbed.

Although highly prized from very ancient times for its unique aroma, it is only recently that vanilla has attracted more attention from plant physiologists, histologists and biochemists [1, 12-15]. One of the major targets in research on vanilla is obviously the biosynthesis pathway of vanillin, its major aroma compound, which implies that interest is focused on enzymes themselves [13, $16,17]$ and sites of synthesis and accumulation [10, 18]. Another research domain concerns the vanilla lipids which may participate to some extent in its aroma [12].

As stated, most works have been focused on the anatomical localization and enzymatic mechanisms of vanillin synthesis and release from its non-aromatic precursor, 4$O$-(3-methoxy-benzaldehyde)- $\beta$-D-glucoside (glucovanillin), all these efforts being made for a better understanding of aroma genesis through diverse technological processes applied to vanilla pods for production of marketable vanilla [5, 7, 9-11, 13, 18-22]; an improved knowledge of these complex mechanisms could ultimately lead to metabolic engineering of vanilla to, for instance, increase the levels of desirable metabolites such as vanillin [15, 23].

Three recent important breakthroughs were the anatomical localization of glucovanillin in the inner region of green mature pods (Odoux et al., July 2003, [10]), very 


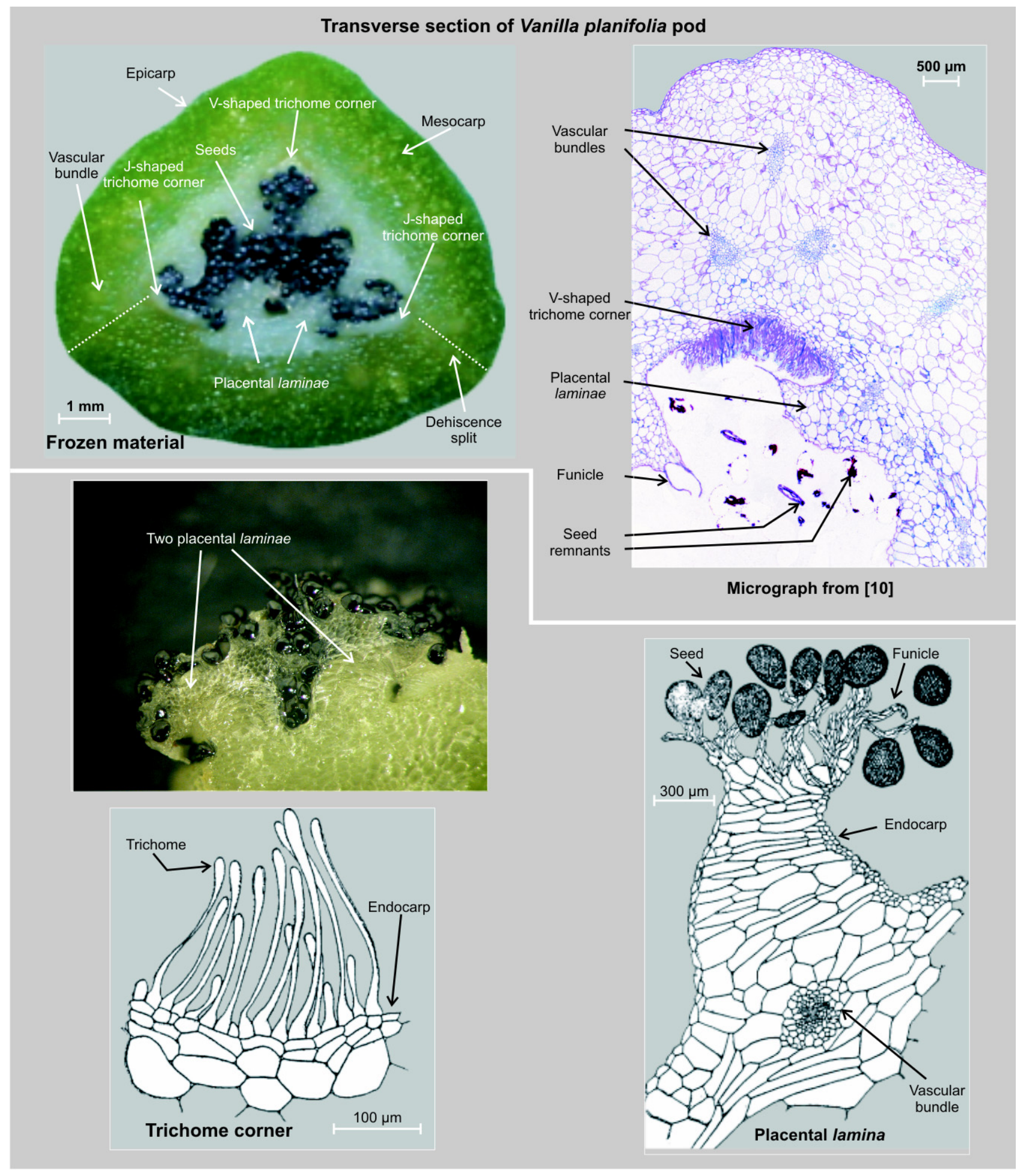

Figure 2.

Split anatomy of vanilla pod (drawings from [9]); 2 placental laminae, photograph from Odoux (2008); micrograph from [10]. 


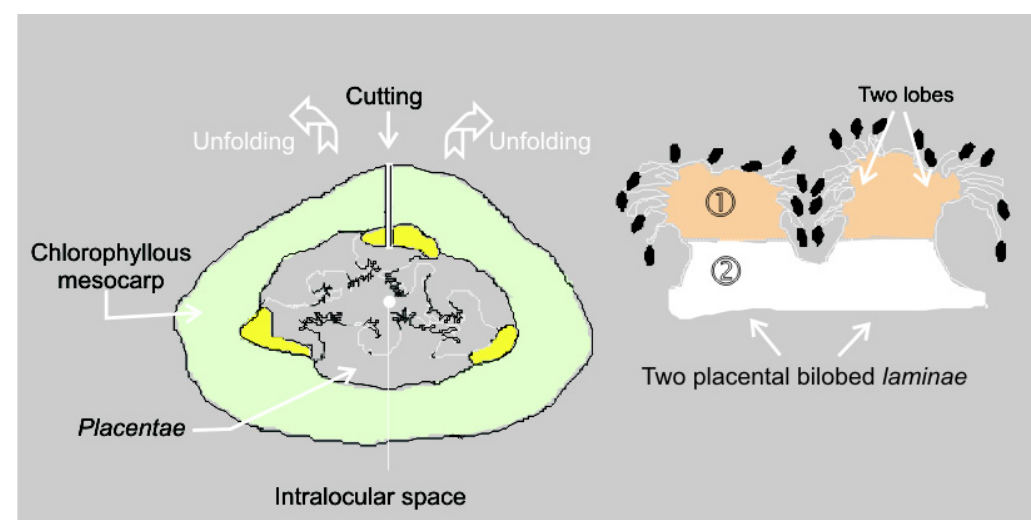

Transverse section

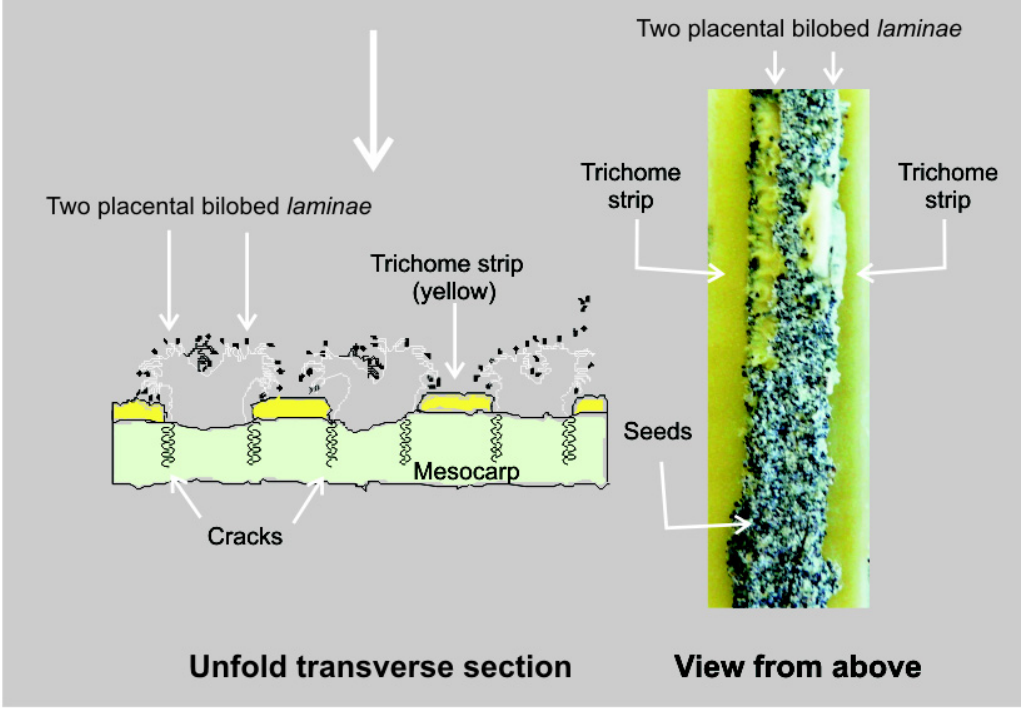

Figure 3.

Mode of dissection of trichome strips and placental lobes of vanilla pods (not to scale). lyzed and release vanillin. Since then, an extremely detrimental confusion has developed and still exists concerning the in vivo sites of vanillin synthesis and accumulation of glucovanillin and of its enzymatic hydrolysis. Odoux et al. [10] demonstrated that glucovanillin accumulates mainly in the placentae and to a lower extent in the trichomes, while Joel et al. [18] asserted soon afterwards that vanillin, as measured after hydrolysis of its glucoconjugate, is synthesized in a unique hairy tissue, the trichomes. Former authors showed that the enzyme had exactly the same anatomical localization as its substrate and that it is cytoplasmic and/or apoplasmic (not vacuolar); liberation of vanillin from its precursor would not therefore be conditioned by a hypothetical outward diffusion of glucovanillin, as mentioned by Arana [19]. Another matter of confusion concerns the final fate of vanillin: as a confirmation of hearsay reported in Swamy's writings who literally and only wrote "unicellular hairs [i.e., the trichomes] are said to secrete the vanillin." [5], Joel et al. [18], also quoted by Havkin-Frenkel and Belanger [15], asserted that vanillin is secreted by trichomes as part of a "densely packed secreted matrix that accumulates in the fruit cavity". However, no quantitative proof of that had ever been provided.

The purpose of our contribution is thus, through reconsideration of our formerly published data [10] and of the previous and recent literature, and by providing new, detailed quantitative data, to unveil and underline indisputable facts with regards to the fate of vanillin in the vanilla pod. The five main compartments of the pod [(mesocarp + epicarp), placentae, trichomes, seeds, and interstitial intralocular cell-free region] were meticulously separated and accurately analyzed for their basic constituents (sugars, organic acids, proteins, cell walls and oleoresin) and phenolics including their glucosylated forms, and their tissue mass distribution is presented. Finally, through a cross-examination of already published results and anatomical, histochemical and biochemical data given in the present work, we propose an evidence-based picture of the sites of accumulation of glucovanillin in the green mature pod. 
Oleoresin, firstly defined as a volatile oil containing resin [24], is nowadays widely accepted as an "oil containing non-resinous materials" obtained from certain plants (e.g., Capsicum spp., Cisteacae). However, in the perfume industry, in the case of vanilla, the meaning of "oleoresin" was extended to a hydroalcoholic extract of the pods [25], thus containing in addition to lipophilic materials phenolics such as vanillin and its glucoconjugate, glucovanillin; this "oleoresin" can be further fractionated, giving a liposoluble fraction. Vanilla pods are oleoresin-rich (3\% of fresh weight) [25]. Long-chain $\gamma$-pyranones were isolated from a pentane extract (the liposoluble "oleoresin" fraction) of whole non-dissected crushed vanilla pods [12] and were said to arise from epicuticular wax. We now report on the exact tissue localization of oleoresin long-chain $\gamma$-pyranones in the vanilla pod and their fluorescence properties

Moreover, a thorough, extensive characterization of the unknown mucilaginous substance secreted into the locule is presented for the first time. With respect to suspected functions of pistil mucilaginous polysaccharides with regards to pollen tubes [26], its possible role in the vanilla pod is discussed.

\section{Materials and methods}

\subsection{Plant materials}

Fifty sound mature green vanilla pods ( $\sim 8$ months after pollination) were used from Kerala State (India). At this maturity stage, i.e., green mature non-dehiscent, they will be designated as vanilla pods throughout our paper. A sample of ten pods was randomly chosen amongst this population. Their average weight was: $(22.38 \pm 1.83) \mathrm{g}$ $(n=10)$. It had been formerly checked [27] on five rings (2-mm width) regularly distributed along the central pseudoprismatic zone of fresh pods (figure 1, 1/3 of the pod length) $(n=5)$ that, within a single pod, concentrations of glucovanillin and other related phenolics were constant. Other vanilla pods were from Gutiérrez Zamora (Veracruz, Mexico).

\subsection{Light microscopy}

Transverse slices (1-mm thickness) were dipped in $0.1 \mathrm{M}$ phosphate buffer ( $\mathrm{pH} 7.0)$ containing $1 \%$ glutaraldehyde, $2 \%$ paraformaldehyde and 1\% caffeine. The medium was placed under vacuum for $15 \mathrm{~min}$, and sections left to incubate for $24 \mathrm{~h}$ at $4{ }^{\circ} \mathrm{C}$. Samples were then dehydrated by successively dipping in $70 \%$ ethanol for $30 \mathrm{~min}$, $95 \%$ ethanol for $2 \times 30 \mathrm{~min}$, and ethanol for $8 \mathrm{~h}$. They were then impregnated in a medium containing Technovit 7100 resin (100 mL; Kulzer Werheim, Germany) to which had been added Technovit 7100 accelerator (1 g), Technovit polyethylene glycol PEG $400(2 \mathrm{~mL})$, and triethylene glycol dimethacrylate $(0.4 \mathrm{~mL})$ diluted twice with ethanol for $2 \mathrm{~h}$ at $4^{\circ} \mathrm{C}$. Samples were impregnated for $24 \mathrm{~h}$ at $4^{\circ} \mathrm{C}$ in the undiluted impregnation medium before they were finally embedded at $37^{\circ} \mathrm{C}$ in the impregnation medium $(15 \mathrm{~mL})$ with $1 \mathrm{~mL}$ of Technovit 7100 hardener. Sections $(5 \mu \mathrm{m})$ were obtained with a Historange LKB microtome. They were then oxidized for $5 \mathrm{~min}$ in $1 \%$ periodic acid, washed with distilled water and stained in the dark for $10 \mathrm{~min}$ with Schiff reactant (PAS) prepared as follows: dispersion of basic fuschin (CI 42500; $1 \mathrm{~g})$ in boiling water $(200 \mathrm{~mL})$, filtering the solution once it was cooled to $50^{\circ} \mathrm{C}$, and adding sodium metabisulfite (2 g) and $1 \mathrm{M} \mathrm{HCl}(20 \mathrm{~mL})$; then, after $24 \mathrm{~h}$ in the dark, activated charcoal ( $0.5 \mathrm{~g})$ was added, and the medium filtered. Sections were washed with distilled water until the washing liquid was colorless and then stained with Naphtol Blue Black [(CI 20470); $1 \mathrm{~g}$ in $7 \%(\mathrm{v} / \mathrm{v})$ ] for $5 \mathrm{~min}$ at $60{ }^{\circ} \mathrm{C}$. Sections were quickly washed with distilled water, then treated with $7 \%$ acetic acid, and finally dried for $15 \mathrm{~min}$ at $60^{\circ} \mathrm{C}$. Sections also underwent a Sudan Red 7B histochemical test for total lipids [28]. Standard control procedures were conducted at the same time. Sections were examined under a DMRXA Leica microscope (Leica Microsystems, Wetzlar, Germany).

\subsection{Fluorescence microscopy}

Fresh cross-sections $(100 \mu \mathrm{m}) \quad$ were obtained from pods using a Microm 
vibratome and observed with a Leica DM6000 epifluorescence microscope (filter cube A, excitation BP 340-380 nm, emission LP $425 \mathrm{~nm}$ ) (Leica Microsystems, Rueil-Malmaison, France). Images were processed through Volocity 4.0.1 (Improvision, Lexington, MA, USA).

\subsection{Dissection of vanilla pods}

Estimation of the fresh mass distribution of the five compartments [(mesocarp + epicarp), placentae, trichomes, seeds, and locule seed-free acellular space] forming a vanilla pod was conducted as follows: the central pseudoprismatic zone of a fresh pod (figure 1) was transversally divided with a razor blade into several cylinders $(\sim 2-\mathrm{cm}$ height); they were then frozen $\left(-20^{\circ} \mathrm{C}\right)$. A cylinder was then longitudinally cut with a scalpel at the angle opposite to the two angles where the dehiscence splits are (figures 2, 3), and penetrating into the locule not further than the mesocarp width to avoid damaging inner placentae and seeds; it was then unrolled from the two ends showing the inner faces of the pseudoprism constituting three paired placental laminae carrying seeds and three intermediate wellvisible seed-free faint yellowish strips located at the locule corners and separated from placental laminae by frost-generated longitudinal cracks, the trichomes. The surface of placental laminae was gently scraped with a spatula to remove most of the seeds, remnant ones being eliminated by gently brushing placentae with a smooth paint brush. Trichome faint yellowish strips were separated from the placental laminae under the stereo microscope with a scalpel running along their long sides and following cracks; strips (width $2 \mathrm{~mm}$ ) were then cut into squares (length $2 \mathrm{~mm}$ ), pinned on the edge, and meticulously separated from the underlying green mesocarp with a razor blade. The same was done to recover the placental laminae.

Placental laminae were submitted to a secondary dissection: under the stereo microscope, laminae were pinned on the edge and meticulously separated with a razor blade into their upper portion (1: the lobes themselves) and their feet (2: the base of laminae) (figure 3).
The intralocular interstitial cell-free medium surrounding the seeds was obtained as follows: portions of fresh pods were longitudinally cut through the V-shaped trichome corner and dipped in pentane. Spontaneously detached seeds were recovered and, after elimination of remnants of funicles with tweezers under the stereo microscope, dried at ambient temperature for $4 \mathrm{~h}$; at that stage, the mucilaginous gangue adheres upon drying to the seeds and was then analyzed for phenolics. A separate preparation of seeds was rapidly washed with distilled water ( $2 \mathrm{~min}$ ), and seeds were analyzed for phenolics after drying.

New scalpels and razor blades were used for each step to avoid cross-contamination of the different tissues. Histological purity of the four tissues was checked under the stereo microscope.

\subsection{Determination of glucovanillin and related phenolics}

Portions of mesocarp, placentae, trichomes, seeds embedded in their watery and oily gangue, and washed seeds ( $50 \mathrm{mg}$ each, dry weight) were extracted by $2 \mathrm{~mL}$ of [methanol:water] $(50: 50, \mathrm{v} / \mathrm{v})$ for $2 \mathrm{~h}$ at ambient temperature with intermittent sonication, then centrifuged (14000 g, $5 \mathrm{~min})$; the supernatant was then submitted to quantitative analysis. HPLC separation of phenolics and their glycoconjugates was performed using an Agilent 1100 separation system (Agilent Technologies, Waldbronn, Germany) including a quaternary pump coupled to a diode array detector and controlled by Chemstation A.10.02 software. Separations were achieved using a [(250 $\times$ 4.6)-mm internal diameter] Modulocart QSLichrospher 5- $\mu \mathrm{m}$ ODS2 column (Interchim, Montluçon, France) with a guard column, operated at $30^{\circ} \mathrm{C}$. The mobile phase consisted of [water:formic acid] (98:2, v/v) (eluant A) and [water:acetonitrile:formic acid] $(18: 78: 2, \mathrm{v} / \mathrm{v} / \mathrm{v})($ eluant B). The flow rate was $0.5 \mathrm{~mL} \cdot \mathrm{min}^{-1}$. The elution program was as follows: $8-13 \%$ eluant $\mathrm{B}$ (0-10 min); 13$20 \%$ eluant B (10-30 min); $20-8 \%$ eluant B (30-35 min). Triplicate samples were injected at a level of $10 \mu \mathrm{L}$. The column effluent was monitored at $280 \mathrm{~nm}$. The 
column eluate was then split and $0.25 \mathrm{~mL} \cdot \mathrm{min}^{-1}$ was directed to a LCQ ion trap spectrometer fitted with an electrospray interface (Thermo Finnigan, San Jose, USA). Experiments were conducted in both negative and positive modes. Scan range was 100-2000 atomic mass unit (a.m.u.) and scan rate $1 \mathrm{scan} \cdot \mathrm{sec}^{-1}$. The desolvation temperatures were $(250$ and 300$){ }^{\circ} \mathrm{C}$ in the positive and negative ion modes, respectively. High spray voltage was set at $4000 \mathrm{~V}$ (positive) and $3500 \mathrm{~V}$ (negative) ion modes. Nitrogen was used as the dry gas at a flow of 5 for the auxiliary gas and 55 for the sheath gas. Identifications were achieved on the basis of the ion molecular masses, UVvisible spectra and injection (+co-injection) of standards when available.

Quantification was achieved by injection of solutions of known concentrations of glucovanillin, $\rho$-hydroxybenzaldehyde, vanillic acid and vanillin; glucosides were quantitatively hydrolyzed by sweet almond $\beta$-glucosidase and released aglycons were converted into their glucosides [29]. Data were obtained from ten separate dissections and expressed as $\mathrm{mg} \cdot 100 \mathrm{~g}^{-1}$ fresh weight. These aglycons and their glucosides will be thereafter designated as "phenolics"; the glucosides themselves will be named "aroma precursors".

\subsection{Extraction of the crude mucilage}

Fresh trichomes ( $\sim \mathrm{g}$ ) were disintegrated in pentane and, after filter paper filtration, dipped in distilled water $(50 \mathrm{~mL})$; the slurry was left under magnetic stirring for $2 \mathrm{~h}$. After centrifugation ( $14000 \mathrm{~g}, 5 \mathrm{~min}$ ), the crude mucilage was precipitated from the water phase by adding ethanol to $80 \%$ final concentration. After standing overnight at ambient temperature, the fresh mucilage was recovered by centrifugation, freeze-dried and weighed.

\subsection{Determination of water and oleoresin}

Viscous material contaminating bits of placental laminae and trichome strips, and seeds, was very quickly blotted with a filter paper (5s) without exerting pressure and the four fresh compartments (including the mesocarp) from a single pod were weighed, dipped in pentane and left under magnetic stirring overnight; the mesocarp, placentae and trichomes were primarily torn to pieces with tweezers while seeds were crushed in a mortar. They were then withdrawn from the solvent, which rapidly evaporated $(30 \mathrm{~s})$; then the fresh materials were weighed, left overnight in a vacuum oven at $80{ }^{\circ} \mathrm{C}$, and weighed again. They were then pulverized in liquid nitrogen into a fine powder with a Dangoumeau ball mill (top impact frequency). Data were obtained from ten separate dissections.

A bulk amount of oleoresin was prepared as follows: vanilla pods ( $60 \mathrm{~g})$ were frozen and the outer part was eliminated with a hand vegetable peeler (no green color left); trichomes were then hand-dissected and seeds were eliminated by flotation in cold water $\left(4^{\circ} \mathrm{C}\right)$. The seed-free trichomes were disintegrated in hexane ([solvent:wet matter] ratio 10) with an ultra-Turrax. After filtration, the organic phase was recovered and excess distilled water added, and the medium was sonicated for $1 \mathrm{~h}$; after centrifugation (14000 g, $5 \mathrm{~min}$ ), the organic phase was again water-washed three times; a clear deep yellow oleoresin was finally obtained by vacuum evaporation of the solvent (yield $0.6 \mathrm{~g})$.

\subsection{Determination of sugars and organic acids}

The dry defatted mesocarp, placentae and trichomes ( $\sim 5 \mathrm{mg}$ each, dry solids) were extracted by $500 \mu \mathrm{L}$ of acidified distilled water ( $\mathrm{pH} 2.3$ ) for $2 \mathrm{~h}$ at ambient temperature then centrifuged ( $14000 \mathrm{~g}, 5 \mathrm{~min})$. HPLC analyses were performed using a SpectraSERIES separation system P100 (Thermo Separation Products, USA) including a quaternary pump coupled to a diode array detector and controlled by Chemstation A.10.02 software. Separations were achieved using a [(250 × 4) mm i.d.) Lichrospher $100 \mathrm{RP} 18 \mathrm{e}$ $(5 \mu \mathrm{m})$ column (Interchim, Montluçon, France) with a guard column, operated at $40{ }^{\circ} \mathrm{C}$. The mobile phase consisted of [methanol:0.01 M phosphoric acid] (30:70, 
$\mathrm{v} / \mathrm{v})$. The flow rate was $0.7 \mathrm{~mL} \cdot \mathrm{min}^{-1}$. Duplicate samples were injected at a level of $20 \mu \mathrm{L}$. The column effluent was monitored at $210 \mathrm{~nm}$ with a Shimadzu differential refractometer. Quantification was achieved by injection of solutions of known concentrations of sucrose, glucose, fructose, and oxalic and malic acids; data were expressed as $\mathrm{mg} \cdot 100 \mathrm{~g}^{-1}$ fresh weight.

\subsection{General}

Determination of nitrogen was performed as follows: after pyrolysis under oxygen at $1050{ }^{\circ} \mathrm{C}$, nitrogen oxides were reduced into $\mathrm{N}_{2}$ which was measured with a catharometer. Cell walls were measured according to Huber [30]. Polysaccharides constituting neutral sugars were determined, after hydrolysis with $2 \mathrm{M}$ trifluoroacetic acid for

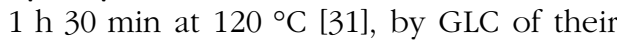
alditol acetate derivatives [32] at $210^{\circ} \mathrm{C}$ on a fused-silica DB-225 capillary column [(30 × 0.32) $\mathrm{mm}$ i.d.], $0.25-\mu \mathrm{m}$ film; J\&W Scientific] with $\mathrm{H}_{2}$ as the carrier gas; inositol was the internal standard. Uronic acids were measured by the m-phenylphenol method [33] using galacturonic acid as a standard. Uronic acids were also identified from the acid hydrolyzate by separation through high pH anion-exchange chromatography (HPAEC) as described by Brillouet et al. [34]. Methylation structural analysis of the polysaccharides was performed with sodium methyl sulfinyl carbanion and methyl iodide in dimethyl sulfoxide [35]; partially methylated alditol acetates were analyzed as described by Pellerin et al. [36].

The fluorescence spectrum of oleoresin was measured with a F-4500 Hitachi spectro-fluorimeter. Oleoresin constituents were separated by HPLC using the same system and column used for analysis of phenolics. The mobile phase consisted of acetonitrile (eluant A) and dichloromethane (eluant B). The flow rate was $0.8 \mathrm{~mL} \cdot \mathrm{min}^{-1}$. The elution program was as follows: eluant A 100\% (0$4 \mathrm{~min}$ ); $100-45 \%$ (4-5 min); 45-20\% (5$20 \mathrm{~min}$ ); $20-100 \%$ (20-25 min). Oleoresin was diluted in [hexane:dichloromethane] $(2: 1, \mathrm{v} / \mathrm{v})$, then duplicate samples were injected at a level of $10 \mu \mathrm{L}$. The column effluent was monitored with a 1100 diode array detector at $260 \mathrm{~nm}$ (Agilent Technologies) coupled to a RF-10AXL Shimadzu fluorescence detector.

\section{Results}

\subsection{Anatomy of green mature vanilla pods}

Observing anatomical and histological elements from the outside towards the central locule of the fruit (figures 1,2) makes it possible to find: a thin epicarp ( $\sim 20 \mu \mathrm{m}$ thickness) covered with a cuticle; a fleshy photosynthetic greenish mesocarp ( 3-mm thickness) made of parenchymatous cells embedding several vascular bundles; three yellowish placentae bearing six longitudinal bi-lobed placental paired laminae onto which seeds are attached through funicles; three vitreous hairy areas (trichomes) located at the three corners of the pod; and a two cell-layered endocarp. French noted that the trichomes, although adjacent to the placentae, are not attached to them [11], i.e., they have no physical contact with placental cells, being simply bound through their distal ends to endocarpic cells. Upon section, the vanilla pod exhibits two easily visible dehiscence lines.

The whole set of data given in this paper will refer to the five main compartments constituting a vanilla pod: (1) the mesocarp (+ epicarp), (2) placentae, (3) trichomes, (4) seeds and the intralocular interstitial cell-free region defined as the watery and oily space surrounding seeds in the locule (5). Due to minute expected masses, no efforts were made to dissect the epicarp separately; similarly, funicles were taken with the placentae. Furthermore, only the pseudoprismatic zone (figure 1) will be considered since distributions might be rather different at the apical and distal ends due to higher weight proportions of vascular bundles.

It is also very important to recall the already mentioned fact that, after freezing a pod, a well demarcated faint yellowish trigone becomes well visible (figure 2 and [10]); it corresponds to the placentae and trichomes (see below). 
Since Joel et al. [18] asserted that phenolic substances are secreted into the apoplasm (i.e., into the cell-free space surrounding seeds), specific attention was paid to the intralocular interstitial cell-free volume. It was measured or calculated by three means and the result checked as follows: relative surfaces of the mesocarp (S1), placentae (S2), trichomes (S3), and locule (S4) were obtained by cutting them out from a hard paper photograph of a pod transverse section (figure 4); after weighing, through paper density, the percent surfaces were calculated; given that the total surface of the transverse section was $51.75 \mathrm{~mm}^{2}$, the total locular surface (S4) was $10.9 \%$ of the whole, i.e., $5.67 \mathrm{~mm}^{2}$. Although seeds are bulbous and pseudospherical [6, 9], for a simpler calculation, we assimilated a seed to a sphere of $230 \mu \mathrm{m}$ diameter; we covered the available locule surface with a maximum number of seed disks (surface of a seed section $\mathrm{S} 5=4.15 \times 10^{4} \mathrm{\mu m}^{2}$; volume of a seed $=$ $\left.6.37 \times 10^{-3} \mathrm{~mm}^{3}\right)$. Going to a ring of $5.67 \mathrm{~mm}^{2}$ and $230 \mu \mathrm{m}$ thickness (= a seed diameter), it came to a maximum of 117 seeds packed in an intralocular seed monolayer. Knowing that the volume of this ring is $1.30 \mathrm{~mm}^{3}$ and that the total volume of seeds is $0.75 \mathrm{~mm}^{3}$, then the empty volume was $0.55 \mathrm{~mm}^{3}$, i.e., $\sim 43 \%$ of the locular total volume. Finally, we filled a graduated tube with glass beads $($ diameter $=0.8 \mathrm{~cm})$ up to $60 \mathrm{~mL}$ (bead diameter and total volume proportional to actual seed diameter and total locular volume) and added water up to the surface of the beads: interstitial volume was found to be equal to $26 \mathrm{~mL}$ ( $\sim 43 \%$ of total volume) and the number of beads to 115 . By counting seeds on a fresh section under the stereo microscope, it came to $\sim 120$. Thus, on average, 117 seeds are contained in a tranverse section of $230 \mu \mathrm{m}$ thickness.

The mesocarp (S1), placentae (S2) and trichome (S3) surfaces were (33.5, 10.5 and 2.1) $\mathrm{mm}^{2}$, respectively. Finally, the percent distribution of volumes in the pseudoprismatic portion of a green mature vanilla pod was: [mesocarp:placenta:trichomes:seeds: intralocular interstitial cell-free medium] = [64.7:20.3:4.1:6.2:4.7]. The inter-trichome volume was neglected in this estimation since French stated that these hairs become

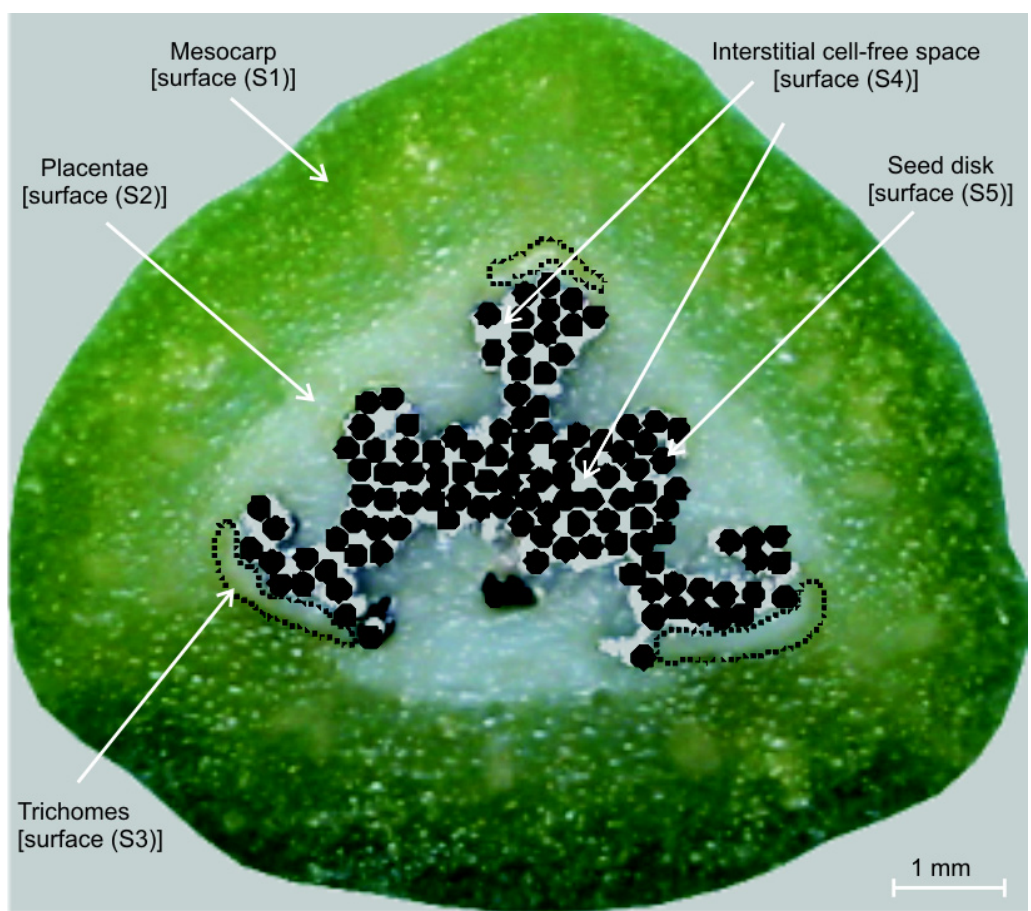

cemented upon aging [11]. Finally, the densities of the respective compartments were: [mesocarp:placentae: trichomes:seeds] = [1.00:1.07:0.88:0.85]; they may be compared with their respective oleoresin and water Figure 4.

Mode of estimation of the intralocular interstitial cell-free volume of vanilla pods (seed diameter: $230 \mu \mathrm{m})$.

\subsection{Distributions of fresh masses, dry solids and organic materials in mature green vanilla pods}

The five compartments from ten green mature frozen vanilla pods were obtained by hand-dissection, and more specifically for trichomes and placental lobes (figure 3). Due to their minuteness, hand-dissection of trichomes required a specific technique greatly facilitated by frost-generated cracks which formed through the mesocarp at the boundary between placentae and hairs. Fresh materials were weighed separately for each pod. Most of the fresh pod matter is made of the fleshy mesocarp followed by the placentae; trichomes, seeds and the intralocular interstitial cell-free medium each represented $\sim 4-5 \%$ of the pods (table I); until now, the mass proportion of trichomes had not been determined. 
Table I.

Distribution of fresh matter and dry solids contents from vanilla pods ( $\%$ of fresh matter, $n=10$ ).

\begin{tabular}{lrrrr}
$\begin{array}{l}\text { Compartments } \\
\text { of vanilla pods }\end{array}$ & Fresh matter distribution & Water & Oleoresin ${ }^{1}$ & Dry solids $^{2}$ \\
\hline Mesocarp & $64.65 \pm 2.35$ & $87.66 \pm 2.05$ & $0.82 \pm 0.09$ & $11.52 \pm 0.27$ \\
Placentae & $21.79 \pm 1.10$ & $80.75 \pm 3.69$ & $1.49 \pm 0.25$ & $17.76 \pm 0.82$ \\
Trichomes & $3.60 \pm 0.22$ & $49.65 \pm 5.12$ & $43.71 \pm 6.02$ & $6.64 \pm 0.80$ \\
Seeds & $5.25 \pm 0.15$ & $13.33 \pm 1.15$ & $32.31 \pm 2.15$ & $54.36 \pm 2.35$ \\
Intralocular cell-free medium & 4.71 (calculated) & Not determined & Not determined & Not determined \\
\hline${ }^{1}$ Oleoresin = materials soluble in pentane. & & & \\
${ }^{2}$ Dry solids = [fresh matter) - (water + oil)]. & & & \\
\end{tabular}

Table II.

Organic composition of vanilla pods (\% of fresh matter, $n=10$ ).

$\begin{array}{lcccc}\begin{array}{l}\text { Compartments } \\ \text { of vanilla pods }\end{array} & \begin{array}{c}\text { Proteins } \\ (\mathrm{N} \times 5.7)\end{array} & \text { Sugars }^{1} & \text { Organic acids }{ }^{2} & \text { Cell walls } \\ \text { Mesocarp } & 0.48 \pm 0.05 & 2.94 \pm 0.15 & 0.53 \pm 0.04 & 5.08 \\ \text { Placentae } & 1.09 \pm 0.05 & 3.02 \pm 0.22 & 1.12 \pm 0.03 & 3.24 \\ \text { Trichomes } & 0.29 \pm 0.09 & 1.51 \pm 0.09 & 0.03 \pm 0.01 & \text { Not determined } \\ \text { Seeds } & 4.27 \pm 0.11 & - & - & - \\ { }^{1} \text { Sugars = glucose + fructose + sucrose. } & & \\ { }^{2} \text { Organic acids = oxalic + malic acids. } & & & \\ \end{array}$

Dry solids were defined as the residue left after extraction by pentane and vacuum heat-dehydration. The materials soluble in this solvent (oleoresin) were liquid and oily at ambient temperature and were considered separately. Dry solids were unequally distributed between compartments from the very rich seeds to the very poor trichomes (table I); the dry solid contents of the mesocarp and placentae differed by $\sim 6 \%$ in favor of the latter, which could be related to placental glucovanillin content. The trichome water content was $\sim 50 \%$ only (fresh weight basis), which explains their very low dry solids content.

Proteins $(\mathrm{N} \times 5.7)$, as percent of fresh matter, were more represented in the placentae than in the mesocarp and trichomes (table II). If one expresses protein content of the water phase only of each tissue (excluding oleoresin), then it comes to: mesocarp $0.55 \%$, placentae $1.35 \%$ and trichomes $0.58 \%$; again, placentae appear $\sim 2.5$ times richer than the two other compartments; indeed, placental laminae were more strongly bluish-stained than the mesocarp by the Naphtol Blue Black (protein material), indicating a high metabolic activity [10]. Knowing that an unknown part of the cellular water is contained in the apoplasm, the symplasmic protein concentrations would be even higher.

Soluble sugar contents in the mesocarp and placentae were similar at $3 \%$ (table II); in the case of trichomes, it was $\sim 1.5 \%$ of total fresh matter, but also $\sim 3 \%$ of the hydrated matter. Sucrose, glucose and fructose were the constituting sugars.

\subsection{Distribution of glucovanillin and related phenolics within mature green vanilla pods}

On a fresh matter basis, placentae were found to be richer in glucovanillin (2.2 times) 
Table III.

Distribution of phenolic glucosides and their aglycons in green mature vanilla pods (\% of fresh weight, $n=10$ ).

\begin{tabular}{|c|c|c|c|c|}
\hline $\begin{array}{l}\text { Compartments } \\
\text { of vanilla pods }\end{array}$ & $\begin{array}{l}\text { 4-O-(3-methoxy- } \\
\text { benzaldehyde)- } \beta \text {-D-glucoside }\end{array}$ & $\begin{array}{l}\text { 4-O-(benzaldehyde)- } \beta-D- \\
\text { glucoside }\end{array}$ & $\begin{array}{l}\text { 3-methoxy-4-hydroxy- } \\
\text { benzaldehyde }\end{array}$ & $\begin{array}{l}\text { 4-hydroxy- } \\
\text { benzaldehyde }\end{array}$ \\
\hline$\lambda_{\max }(\mathrm{nm})$ & $272.0,307.6$ & 268.2 & $279.6,309.2$ & 284.2 \\
\hline $\begin{array}{l}(\mathrm{M}+\mathrm{HCOO})^{-} \text {adduct } \\
\text { with formiate ion }\end{array}$ & 359 & 329 & - & - \\
\hline Mesocarp & $0.026 \pm 0.019$ & $0.0006 \pm 0.0004$ & $0.0020 \pm 0.0010$ & $0.0006 \pm 0.0005$ \\
\hline Placentae & $8.589 \pm 1.628$ & $0.0995 \pm 0.0286$ & $0.2010 \pm 0.0760$ & $0.0121 \pm 0.0051$ \\
\hline Bases & $9.634 \pm 1.991$ & $0.1221 \pm 0.0410$ & $0.2420 \pm 0.0610$ & $0.0155 \pm 0.0063$ \\
\hline Lobes & $4.982 \pm 1.273$ & $0.0555 \pm 0.0212$ & $0.1950 \pm 0.0450$ & $0.0079 \pm 0.0028$ \\
\hline Trichomes & $3.932 \pm 1.277$ & $0.1290 \pm 0.0530$ & $0.1470 \pm 0.0430$ & $0.0140 \pm 0.0050$ \\
\hline
\end{tabular}

than trichomes (table III), a ratio slightly lower than our previously reported one (3.3 times) [10] for green mature pods of the same physiological age. It is worth noting that concentrations of glucovanillin in the placentae and trichomes, when expressed as a percent of their respective water phases, are close to each other, as are the levels of sugars (table II). Contrary to our previous study [10], we found, although at trace level (table III), some glucovanillin in the mesocarp, as did Joel et al. [18] (0.56\%, fresh matter basis), and seeds were glucovanillin-free. The glucovanillin mass distribution within a pod was: placentae $92.2 \%$, trichomes $7.0 \%$ and mesocarp $0.8 \%$. On a dry solids basis, it represents $\sim 48 \%$ of the placentae and $\sim 59 \%$ of the trichomes.

In addition to that, the placental laminae were found to be heterogenous for their contents of glucovanillin, $p$-hydroxybenzaldehyde $\beta$-D-glucoside and their aglycons: indeed, a gradient of concentrations was found from their base to the lobes of the laminae (figure 3, table III), lobes being twice as poor as the bases of the laminae.

A different distribution was found for $p$-hydroxybenzaldehyde $\beta$-D-glucoside. Although placentae were the richest compartments (fresh weight basis), the trichomes and mesocarp showed significant levels and its mass distribution was somewhat different from that of glucovanillin: placentae $81.5 \%$, trichomes $17.2 \%$ and mesocarp $1.4 \%$. The average (glucovanillin:p-hydroxybenzaldehyde $\beta$-D-glucoside) concentration relative ratios were also different: [85:1] in placentae, and [31:1] in trichomes. We also carried out a less complete study on green mature pods from Mexico; they were richer in glucovanillin and $p$-hydroxybenzaldehyde $\beta$-D-glucoside was relatively more abundant compared with glucovanillin (respective concentrations: in placentae $11.0 \%$ and $0.5 \%$; in trichomes $1.3 \%$ and $0.2 \%$ ); we found that the above ratio was again different between placentae and trichomes: $\sim[22: 1]$, and $\sim[6: 1]$, respectively. Thus, differently from trichomes, the accumulation of glucovanillin is more largely favored (three to four times) in placentae than $p$-hydroxybenzaldehyde $\beta$-D-glucoside; although the meaning of this difference remains obscure, this suggests a tissue metabolic segregation with regards to the biosynthesis (and/or its regulation) of these two aroma precursors. It must be noted that traces of 4-O-(3-methoxy-benzoic acid)- $\beta$ $D$-glucoside (vanillic acid glucoside) and 4-O-(benzoic acid)- $\beta$-D-glucoside were also found in both compartments.

The concentrations of glucovanillin and related phenolics in the intralocular interstitial cell-free medium embedding seeds were also measured. They were: glucovanillin $27 \mu \mathrm{g} \cdot \mathrm{mL}^{-1}$ and vanillin $5 \mu \mathrm{g} \cdot \mathrm{mL}^{-1}$, for a total level of $\sim 0.003 \%$ in interstitial liquid, i.e., $\sim 0.006 \%$ of the total phenolics contained in the vanilla pod.

Finally, aglycons were also present. Whether they were not yet glucosylated or had been deglucosylated from their parent 
glucoconjugates by vanilla $\beta$-glucosidase is not known [14]. Their levels were, as a percent of total aglycon, i.e., (free + glucosidically-linked), placentae; vanillin 4.5\%, p-hydroxybenzaldehyde $21.8 \%$; trichomes: vanillin $7.1 \%$, p-hydroxybenzaldehyde $20.3 \%$ If the free aglycons arose from the enzymatic deglucosylation of their precursors, one must note a different behavior between these two phenolics which might reflect a different maximum velocity $\left(\mathrm{V}_{\mathrm{m}}\right)$ of the enzyme on these two substrates which was not known until now.

\subsection{Distribution of oleoresin within mature green vanilla pods}

We determined the contents of pentane-soluble materials (oleoresin) in the four compartments [8, 9] (table I). While the mesocarp and placentae showed low levels $(<1.5 \%$, fresh weight basis), the trichomes were found to be extremely rich, with $\sim 45 \%$ of an oily material (fresh weight basis). Such a result was not unexpected since light micrographs of unstained thick fresh sections (figure 5) showed a high density of oily brown-yellow material in their distal and apical portions and droplets of the same color; the trichomes were also intensely reddish-stained by Sudan Red (figure 5), and exhibited a very intense white-bluish fluorescence (figure 5). Placentae showed a weak yellowish fluorescence only. By HPLC, we checked that trichome oleoresin was devoid of glucovanillin and related phenolics, and of fluorescent chlorophyll. Its absorbance and emission spectra showed maxima at $\lambda_{\max }=260 \mathrm{~nm}$, consistent with an enone group [12], and $\lambda_{\mathrm{em}}=458 \mathrm{~nm}$ in hexane $\left(\lambda_{\text {exc }}=325 \mathrm{~nm}\right)$, respectively, corresponding to its fluorescence in the blue range of the visible spectrum. Separation of oleoresin constituents by HPLC afforded a homologous series (compounds 1 to 6 ; figure 6 ) showing a very strong UV absorbance and fluorescence. Peak 3 gave a pseudomolecular ion at $(\mathrm{M}+\mathrm{H})^{+}$at $m / z=433$. We did not detect these compounds in the separately dissected pod epicarp. We also have qualitative evidence (HPLC analysis) that the deep yellow color of the oleoresin is due to the presence of $\beta$-carotene.

\subsection{Distribution and characterization of the mucilage within mature green vanilla pods}

The mesocarp was directly homogenized in distilled water while viscous material impregnating trichome strips and, to a lower extent, placentae was rapidly drained with a filter paper, then was treated like the mesocarp. A mucilaginous material was recovered by precipitation of the extract in $80 \%$ ethanol. The mesocarp and placentae were found to be mucilage-free, while the trichome dry solids consisted of $\sim 32 \%$ of this material which was shown to be essentially polysaccharidic in nature. The feeling of high viscosity obtained when manipulating the seeds with one's fingers is due to the mucilage itself since it was the same with the oleoresin-free one redissolved in water. This huge concentration is reflected by the intense fuchsia periodic acid-Schiff (PAS) staining of the intracellular portion of the tubular cells (figure 5), whereas, in other tissues, only cell wall polysaccharides (cellulose, hemicelluloses and pectic substances) stained fuchsia. The intralocular interstitial cell-free medium was not stained since the excreted water-soluble mucilage was eliminated into the glutaraldehyde fixative solution. Bluish-stained protein material was also visible in the cell-free space. The composition of this polysaccharide mixture shows that uronic acids, arabinose and galactose are the major sugar constituents, followed by mannose and glucose (table IV). Xylose, rhamnose and fucose are minor constituents. After saponification [38], no ester-linked ferulic acid was observed. Structural analysis of this polysaccharide mixture (table $V$ ) reveals a high density of terminal units (arabinose and galactose) and a glucomannan.

\section{Discussion}

To our knowledge, the first mention of an exclusive localization of an unknown vanillin-releasing system in the inner portion of the vanilla pod was given by De Lannessan, who wrote: "The flavouring matter is not contained in the outer fleshy part of the fruit, 


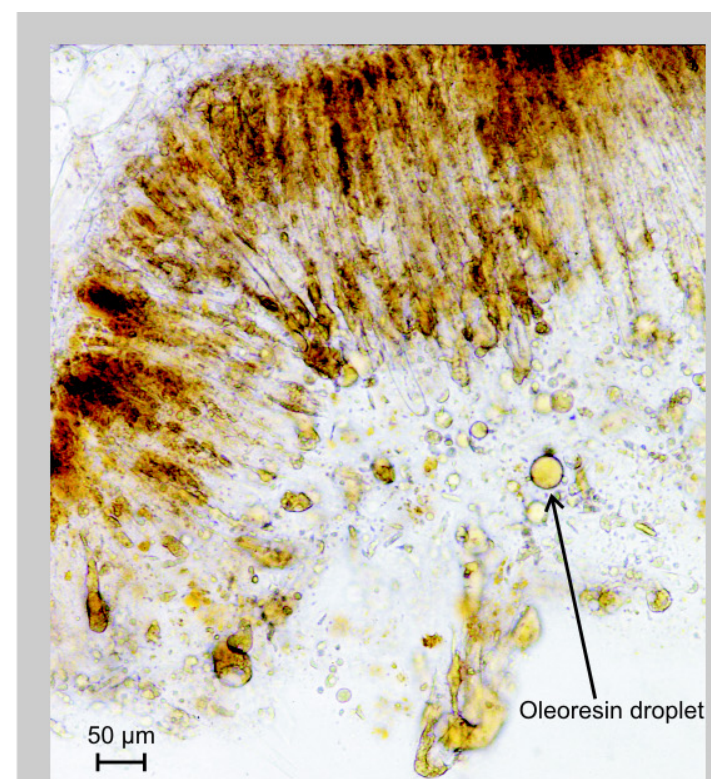

Unstained trichome

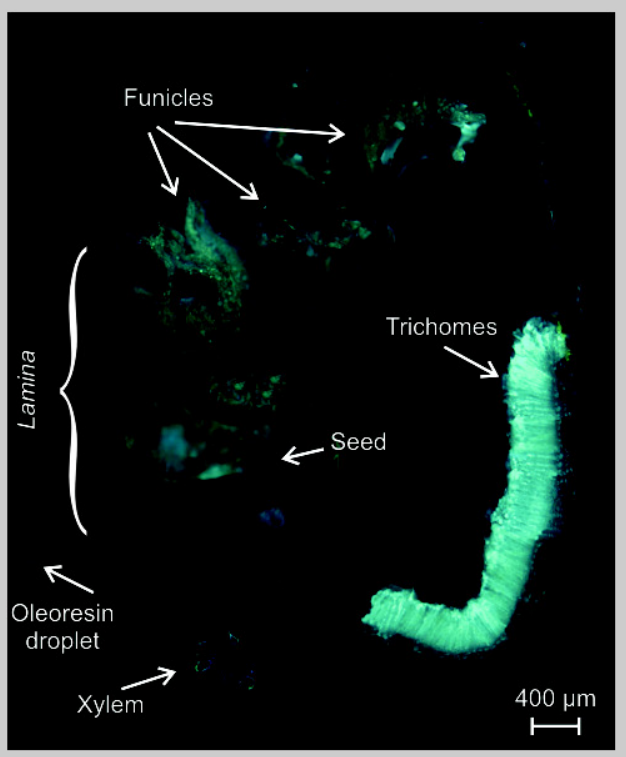

Fluorescence microscopy (J-shaped corner, see figure 2)

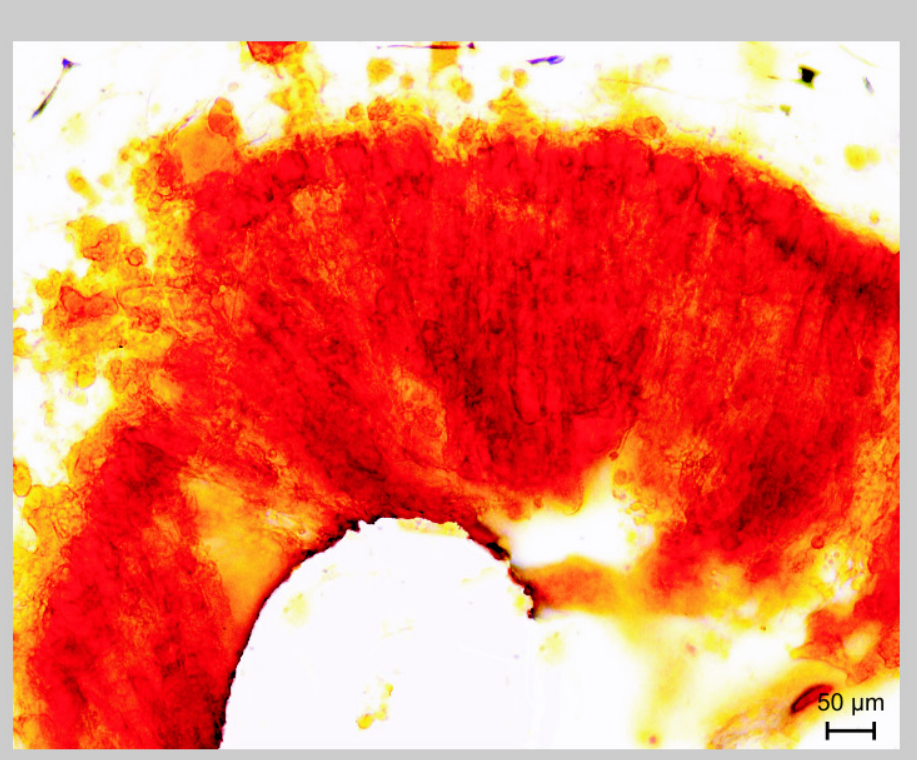

Trichome stained by Sudan Red

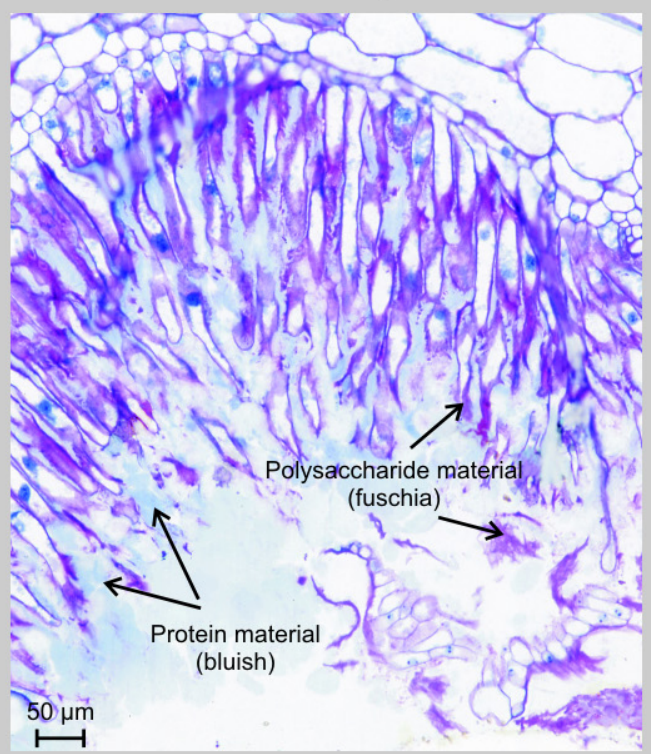

PAS-Naphtol Blue Back since, when cutting it into thin lamellae when fresh, and letting them separately dry, one can observe that only lamellae from the inner region are odorant." [8]. The same year, Mangin wrote: "These fruits are much elongated siliques or capsules with fleshy and thick walls containing an aromatic pulp... That pulp itself is the vanilla; the rest of the fruit is only its envelope." [39]. Thus, anatomically speaking, the vanilla pod, by the end of the nineteenth century (and very likely much earlier), had been experimentally demonstrated as heterogeneous with regards to aroma genesis, i.e., the enzymatic hydrolysis of glucovanillin into vanillin.

We produced recent quantitative evidence of a preferential sequestration of glucovanillin and $\beta$-glucosidase, the two
Figure 5.

Vanilla pod trichome sections (J-shaped corner, see figure 2). 


\section{Figure 6.}

UV- and fluorescence-HPLC chromatograms of trichome oleoresin $(\lambda=260 \mathrm{~nm})$ from vanilla pods.

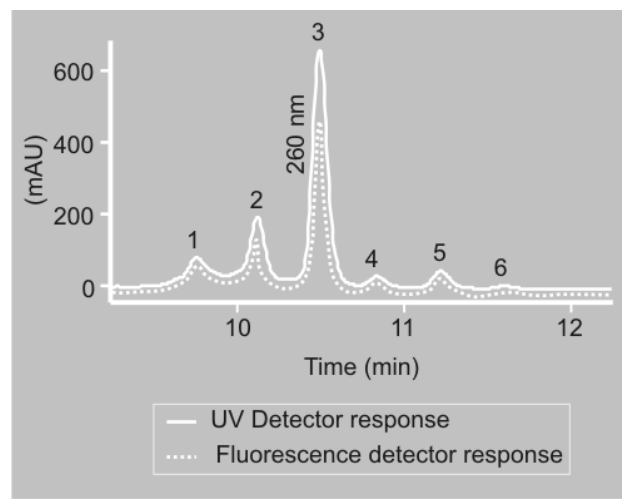

components of the vanillin-releasing system, in the inner pod region (i.e., placentae and trichomes) [10], in agreement with the above quoted authors but in contradiction with previous data by Arana [19]. In the present work, we unambiguously and more definitely proved, through fine dissections, that the glucosylated non-aromatic precursor of vanillin, i.e., glucovanillin, is essentially stored in the placental laminae of the green mature pods ( $\sim 92 \%$ of total glucovanillin), the trichomes containing only about $7 \%$ of it. Regarding the intralocular interstitial cell-free medium, we showed that its glucovanillin content (if any) was infinitesimal. Whether the fleshy photosynthetic mesocarp at the green mature stage could be considered as glucovanillin-free [10] or if it contains a minute proportion of this molecule (this work and [18]) is still a matter of conjecture: indeed, although its hand-dissection was performed under the stereo microscope along the sharp boundary with the whitish placental zone, a slight contamination cannot be excluded, and, for example, a $1 \%$ placental contamination would increase by one-third the mesocarpic glucovanillin content. A recent laser capture microdissection technique coupled with microanalysis [40] could be an efficient approach to tackle this point.
In the aqueous phase of the placentae, glucovanillin showed an estimated concentration of $338 \mathrm{mM}$, a value similar to the one previously reported $(300 \mathrm{mM}$ [10]), but likely to be higher since an unknown part of water is apoplasmic (hydration of cell walls). In the trichome water phase, it reached $252 \mathrm{mM}$. It is worth noting that concentrations of glucovanillin, when expressed as a percent of the water phases of the placentae and the trichomes, respectively, are very similar and so are the levels of sugars. Thus, although these two cell types are ontogenetically, morphologically and functionally (mucilage and oleoresin syntheses in trichomes only) very different, their aqueous phases are very much comparable for their phenolic and sugar contents. Since the maximum solubility of glucovanillin in pure water is lower than $100 \mathrm{mM}$ at ambient temperature (Odoux, unpubl. res.), the actual physico-chemical status of glucovanillin in placentae is not known: the vacuolar medium ( $>93 \%$ of total cell volume [10]) in which glucovanillin is present might be oversaturated due to the presence of other elements (sugars, proteins, etc.). Glucovanillin might also be under crystalline or amorphous insoluble forms although the placental cells appear translucent under the stereo microscope (figure 1). Appearance of a whitish zone, i.e., the placentae, upon freezing (figure 2) leads to favoring the first hypothesis.

The presence of glucovanillin in trichomes was formerly illustrated by their intense epifluorescence under unfiltered UV excitation $[11,18]$. While we observed a bluish-white intense fluorescence of the trichomes (figure 5) and of expelled droplets, we found that placental laminae, although twice as rich in glucovanillin as trichomes, exhibited a faint greenish-yellow fluorescence. More precisely, it is mainly the laminae lobes (i.e., the region where the

\section{Table IV.}

Composition of the trichome mucilage (anhydrosugar mole \%) from vanilla pods.

\begin{tabular}{|c|c|c|c|c|c|c|c|c|c|}
\hline $\begin{array}{l}\text { Yield } \\
\text { (\% fresh trichomes) }\end{array}$ & Rhamnose & Fucose & Arabinose & Xylose & Mannose & Galactose & Glucose & $\begin{array}{c}\text { Glucuronic } \\
\text { acid }\end{array}$ & $\begin{array}{c}\text { Galacturonic } \\
\text { acid }\end{array}$ \\
\hline 2.1 & 0.83 & 0.29 & 24.49 & 2.86 & 11.69 & 18.87 & 8.66 & 25.01 & 7.30 \\
\hline
\end{tabular}


funicles carrying seeds are; figures 1-3) which show significant fluorescence, although far less intense than the trichomes'; one must recall that the placental lobes contain twice less glucovanillin than the bases. These observations are hardly reconcilable with glucovanillin being the unique source of fluorescence. Indeed, trichome oleoresin itself exhibited a strong white-bluish fluorescence due to alkenylmethyl-dihydro- $\gamma$ pyranones (figure O). Ramaroson-Raonizafinimanana et al., when analyzing the unsaponifiable portion of a vanilla integral oleoresin by gas-liquid chromatography (GLC) and NMR spectroscopy, characterized the first three homologs of this (1 to 3 ) series, namely, 2-nonadecen-10-yl, 2-heinecosen12-yl and 2-tricosen-14-yl 2,3-dihydro 6methyl 4H-pyran-4-ones [12] (figure 7). Due to their high molecular weights, the upper homologs ( 4 to 6) were not detected by GLC. These are: 2-pentacosen-16-yl, 2-heptacosen-18-yl and 2-nonacosen-20-yl 2,3dihydro 6-methyl 4H-pyran-4-ones. Although we did not measure them, the relative proportions of the $1 \rightarrow 3$ pyranone homologs reported by Maestro et al. [25] were strictly the same as ours (1:2:3 =0.10:0.41:1).

In conclusion, contrary to the above authors who ascribed the UV fluorescence of the hairy tissue (i.e., the trichomes) to phenolic substances that it secretes into the apoplasm [18], our results demonstrate that their very intense fluorescence is essentially due to alkenylmethyldihydro-pyranones contained in their oleoresin. This is the first mention of their presence in trichomes. Indeed, because they did not dissect their vanilla pods to obtain the epicarp, and extracted neutral lipids from whole crushed beans, Ramaroson-Raonizafinimanana et al. located long-chain $\gamma$-pyranones in epicuticular wax [12], which is devoid of these compounds. In fact, only trichomes seem to contain these pyranones. Although we did not measure their content, they represent, according to Maestro et al., and depending on vanilla pod batches, from $3 \%$ to $25 \%$ of vanilla oleoresin components detected by GLC, i.e., given the huge trichome oleoresin content ( $\sim 5 \%$ fresh weight), from $\sim 1.4 \%$ to $11 \%$ of the trichome fresh weight [25]. Glucovanillin and vanillin weakly fluoresce too at $\lambda_{\text {em }}=410 \mathrm{~nm}$ ([41]; G Conejero, "pers.

\section{Table V.}

Structural analysis of the mucilaginous polysaccharides of vanilla pods.

\begin{tabular}{|c|c|c|}
\hline Sugar derivative & Linkage indicated & Mole \% \\
\hline 2,3,5-Me -arabinose $^{1}$ & terminal furanose & 30.8 \\
\hline 2,3,4-Me ${ }_{3}$-arabinose & terminal pyranose & 5.3 \\
\hline 3,5-Me $-\mathrm{Me}_{2}$ abinose & 2-linked & 0.5 \\
\hline 2,4-Me ${ }_{2}$-arabinose & 3-linked & 0.9 \\
\hline 2,3- $-\mathrm{Me}_{2}$-arabinose & 5-linked & 1.4 \\
\hline 2,3,4,6- $\mathrm{Me}_{4}$-galactose & terminal & 19.5 \\
\hline 2,3,4-Me - -galactose & 6-linked & 2.1 \\
\hline 2,4,6-Me - -galactose & 3-linked & 2.2 \\
\hline 2,4-Me - -galactose & 3,6-linked & 2.6 \\
\hline 2-Me-galactose & 3,4,6-linked & 1.0 \\
\hline 2,3,4,6-Me - -glucose & terminal & 1.1 \\
\hline 2,3,6-Me - -glucose & 4-linked & 12.9 \\
\hline 2,3-Me - -glucose & 4,6-linked & 1.2 \\
\hline 2,3,4,6-Me - -mannose & terminal & 1.6 \\
\hline 3,4,6-Me - -mannose & 2-linked & 0.1 \\
\hline 2,3,6-Me - -mannose & 4-linked & 15.1 \\
\hline 2,3-Me - -mannose & 4,6-linked & 1.7 \\
\hline
\end{tabular}

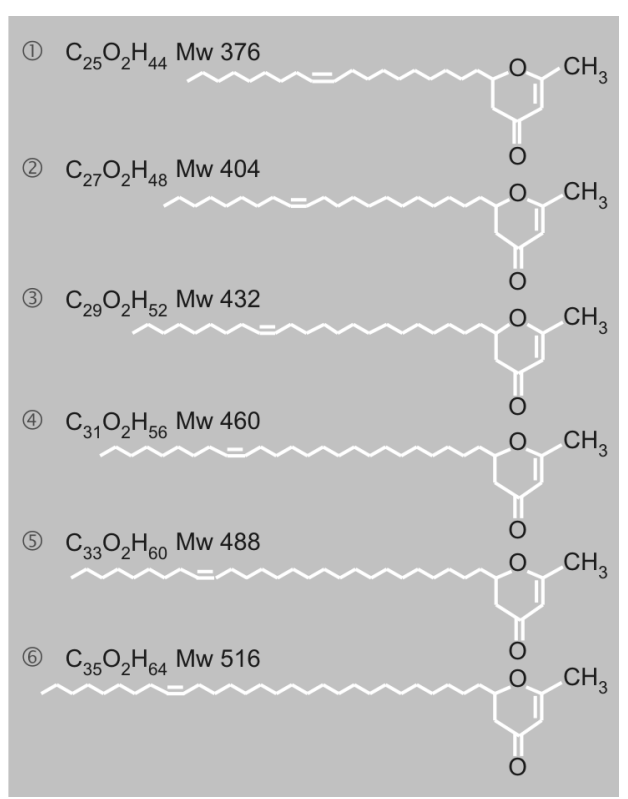

Figure 7.

Structures of alkenylmethyldihydropyranones. commun."), i.e., in the purple range of the visible spectrum, but, although representing $\sim 4 \%$ of trichome fresh weight and since 
placentae fluoresce faintly in the green-yellow range, these phenolics cannot account for the observed trichome brilliant whitebluish fluorescence.

As stated above, within months following our first article, Joel et al. confirmed a favored localization of vanillin (in fact glucovanillin) in the central part of the pod [18] but, this time, attention was focused on the trichome tissue. The authors' assertion that a unique hairy secretory tissue, the trichomes, produces and accumulates (gluco)vanillin is not easily reconcilable with our data. The authors drew a parallel between the elongation rate of tubular cells (trichomes) during maturation and the increase in concentrations of glucosylated forms of $p$-hydroxybenzaldehyde and vanillin in the whitish inner part of the pod (i.e., placentae and trichomes) during the same period. Such pseudoparallel evolution was taken as evidence for the trichomes being a unique tissue synthesizing these phenolics. Later, Havkin-Frenkel and Belanger wrote, quoting the considered article, "the accumulation of these compounds was directly related to the size of inner specialized cells" [15] (i.e., the trichomes). Actually, the placentae and trichomes were undeniably analyzed in admixture, maybe because of the tediousness of separating them properly by dissection; indeed, the reported concentrations were those found in the placentae, not in the trichomes themselves (table III) Although a superposition of histograms can be done for $p$-hydroxybenzaldehyde $\beta$-Dglucoside accumulation and trichome length, this coincidental parallelism does not exist for glucovanillin, which almost reaches its maximum at 5-6 months (trichome length $10 \mu \mathrm{m}$ ) compared with 89 months (trichome length $300 \mu \mathrm{m}$ ) after pollination $(12.5 \%$ vs.14.0\%, fresh weight basis; note that the ordinate axis was scaled by mistake as $\%$ dry weight). Considering all our preceding comments, this ontogenetical character is definitely not valid evidence for the trichomes being the unique site of synthesis and accumulation of glucovanillin and $p$-hydroxybenzaldehyde $\beta$-D-glucoside.

In the same article, Joel et al. [8] produced a confocal micrograph showing a positive immunostaining of trichome cytoplasm with an antibody raised against vanilla $p$-hydroxybenzaldehyde synthase (HBS) [13]; this was also questionably considered as a second piece of evidence of vanillin synthesis in the trichomes. Indeed, the enzyme produces, from $p$-coumaric acid, $p$-hydroxybenzaldehyde, not vanillin. Furthermore, since no experimental details were given for the preparation and characterization of this antibody, one may think that, if it was raised against the enzyme described in the above reference, several kinds of proteins (enzymes) could have been marked, mostly when the two enzyme fractions obtained there were not pure, showing several bands in SDS-polyacrylamide gel electrophoresis. Havkin-Frenkel and Belanger [15], and Havkin-Frenkel and Podstolski for vanilla cell cultures [37], and Sicar and Mitra for carrot hairy roots [42], also mentioned the possibility that the HBS activities which, in both cases, were not purified to homogeneity, could be mediated by several enzymes. In fact, an in situ direct display of the enzymatic activity would have been a more definitive proof.

Joel et al. [18], and Havkin-Frenkel and Belanger [15] displayed a micrograph of the central portion of the pod showing an intense catechin- $\mathrm{HCl}$ staining of a characteristic placental lamina improperly arrowed as the "secreted matrix" (compare their shape in figure 2 and in the above references); this can be viewed as positive indirect evidence of their richness in phenolics as stated in this paper. The authors mentioned a descending staining gradient from the endocarp in the fruit cavity outwards in contradiction with our quantitative data, since we show here that there exists an increasing gradient from the apical ends of the placental lobes towards the base of placental laminae for their contents of glucovanillin, $p$-hydroxybenzaldehyde $\beta$-D-glucoside and their aglycons. We have no suggestion to explain the existence of such a gradient. Secondly, on the same micrograph, the "vanillin secretory tissue", i.e., the trichomes, was not stained red. The authors interpreted this absence of staining of the special cells dedicated to vanillin biosynthesis as indicating that these cells would synthesize flavor compounds and secrete these products into the vicinal tissue region 
and/or into the extra-cellular regions. However, as mentioned by French, trichomes, although being adjacent to placental laminae, are not attached to them [11] (figures 1, 5), but to the underlying endocarpic cells from which they differentiated earlier in their development. Thus, if vanillin were synthesized in trichomes only, how and why would it accumulate in such massive amounts in placental laminae? Trafficking from the trichome symplasm to the laminae would require crossing through several vacuolar and cytoplasmic membranes, cell walls, and the liquid locular gap in between, which seems neither physiologically or histochemically comprehensible, nor energetically feasible. More likely, the non-staining may have a more trivial cause: a perturbation of the catechin- $\mathrm{HCl}$ reaction caused by the presence of $\sim 45 \%$ oleoresin (fresh weight basis; table I) in the trichomes had occurred.

Another matter of controversy is the nature of the secretions produced by the trichomes. Joel et al. [18] altered Swamy's writings [5], since this author never wrote that vanillin is "secreted into tissues around the seeds"; starting from this questionable extrapolation, and referring to their histological observations, they asserted that vanillin (in fact glucovanillin) was secreted by trichomes "into the fruit cavity"; however, no comments were given with regards to the possible physiological function of this so-called "vanillin secretion". Concerning vanillin and its glucoside, we demonstrated here that the quantitatively unsupported suggestion of Joel et al. [18] and the following references about their "secretion" by the trichomes into the intralocular interstitial cell-free medium is almost unprovable in practice; indeed, unpredictable (unavoidable?) minute contaminations by the V-shaped trichome corner may still occur when longitudinally cutting the pseudoprismatic portion, rendering it impossible to ascertain whether the intralocular interstitial cell-free medium is phenolic-free or not. If not, the amount of "secreted" phenolics appears infinitesimal compared with the placental and, accessorily, trichome stocks.

However, the secretory role of trichomes in general has long been well documented in the plant kingdom [43-46]. French, when studying ovular and placental trichomes of Araceae, mentioned their mucilage-secreting activity [45], as did Fahn and Simony for Fragonia species [46]. In the case of vanilla pods, they are known to excrete a mucilage or sticky substance [11] and expel oleoresin droplets [8, 47]. We demonstrate here for the first time that trichomes actually produce massive intracellular amounts of mucilage, polysaccharidic in nature: it is made of a mixture of a typical glucomannan $(\sim 35 \%)$ resembling the Amorphophallus konjac (monocotyledon) glucomannan [48] and of about $65 \%$ of a peculiar pectic polysaccharide. According to its structural analysis (table $V$ ), this latter polymer is a very densely branched polysaccharide ( $\sim 50 \%$ terminal arabinose and galactose) with only a few short chains of 5-linked arabinose, and 3-, 6- and 3,6-linked galactose. Since we did not analyze the structure of the acidic moiety, we are not able at the moment to identify the points of branching, possibly galacturonic acid. French showed that this mucilage is secreted into the intralocular and inter-trichome medium [11]; upon section, it shows in transmission electron microscopy a non-crystalline feather-like criss-cross, suggesting an organized matrix. Similarly, trichomes from Araceae (monocotyledons) produce and secrete enormous quantities of it, which often fill the entire locule [43].

These mucilaginous substances are present on all parts of the gynoecium of many plants [49] and their roles in the facilitation of the pollen tube journey from the stigma to the ovule micropyle are not fully elucidated [26]. Mollet et al. reported that, after extensive water-washing of style fragments from lily (a monocot), a crude polysaccharide mixture was obtained by soaking in $0.5 \mathrm{M}$ imidazole- $\mathrm{HCl}$ buffer $(\mathrm{pH} 7.0)$ [50]; this and a stigma/stylar cystein-rich protein (adhesin) bind to each other and promote adhesion of pollen tubes to the stigma epidermal extracellular matrix. Its chemical composition was very similar to ours with respect to arabinose, mannose, galactose, glucose and glucuronic acid molar ratios. The lily extract was, however, relatively richer in galacturonic acid. Nevertheless, its [galacturonic acid/rhamnose] 
mole ratio (8.3) was similar to ours (8.8). Thus, it seems that, amongst vanilla complex mucilaginous polysaccharides, the pectic fraction would be a typical rhamnogalacturonan I with a high degree of interspersion of rhamnosyl units in the acidic backbone [51]. However, in the case of vanilla, since trichomes differentiate only after fertilization [5], their mucilaginous secretion does not play a part in pollen tube guidance and nutrition; it is not known if similar secretions originating from other cell types exist at the pre-fecundation stage. Finally, the role of this polysaccharidic mucilage in the mature fruit, although having very strong similarities to lily pollen tube adhesion pectin, remains unknown.

\section{Conclusion}

The green mature vanilla pod constitutes swollen placental laminae stuffed with glucovanillin and related phenolics; secretory tubular trichomes filled with oleoresin rich in $\gamma$-pyranone derivatives, glucovanillin and a mucilage, polysaccharidic in nature, also present in the intralocular interstitial cellfree medium; and a fleshy mesocarp devoid of these components. Compared with the placentae, trichomes store minor quantities of glucovanillin. Both placental laminae and trichomes apparently harbor the enzymatic systems for the synthesis of $p$-hydroxybenzaldehyde, vanillin and related phenolics and their further glucosylation. However, the implicated enzymes might be different since multiple routes are possible [52], and their biosynthesis and fate seem to be differently regulated in both compartments. Finally, the physiological roles, if any, of glucovanillin and related phenolic glucosides, long-chain $\gamma$-pyranones, and mucilage remain totally unknown.

\section{Acknowledgements}

We thank C. Dhuique-Mayer (UMR Qualisud, CIRAD, Montpellier, France) for the separation of carotenoids; P. Alter and G. Morel for their helpful technical assist- ance; B. Guyot and N. Durand (UMR Qualisud) for HPLC with fluorescence detection; and F. Lamotte and S. Catrix (UMR DAP, CIRAD-INRA, Montpellier, France) for their help with spectrofluorimetry. We thank G. Conejero (Plant Cell Histocytology and Imaging Platform, CIRAD-MIR, Montpellier, France) for epifluorescence microscopy. We also wish to thank M. Bourgois (Eurovanille, France) for the gift of Indian vanilla pods.

\section{References}

[1] Cameron K., Biogeography of Vanilloideae (Orchidaceae). 16th International Botanical Congress (abstract), St. Louis, Missouri, USA, 1-7 August, 1999.

[2] Portères R., Le genre Vanilla et ses espèces, in: Bouriquet G. (Ed.), Le vanillier et la vanille dans le monde, Lechevalier, Paris, France, 1954, pp. 94-290.

[3] Sotos-Arenas M.A., Vanilla, in: Pridgeon A.M., Cribb P.J., Chase M.W., Ramunsen F.N. (Eds.), Genera Orchidacearum, Oxford Univ. Press, UK, 2003, pp. 321-334.

[4] Stern W.L., Judd W.S., Comparative vegetative anatomy and systematics of Vanilla (Orchidaceae), Bot. J. Linn. Soc. 131 (1999) 353-382.

[5] Swamy B.G.L., On the life history of Vanilla planifolia, Bot. Gaz. 108 (1947) 449-456.

[6] Cameron K.M., Recent advances in the systematic biology of vanilla and related orchids (Orchidaceae: subfamily Vanilloideae), in: Proc. Vanilla, First Int. Cong., Princeton, USA, Carol Stream, Allured Publ. Corp., USA, 2005, pp. 89-93.

[7] Havkin-Frenkel D., French J.C., Pak F., Frenkel C., Inside vanilla: Vanilla planifolia's botany, curing options and future market prospects, Perfum. Flavour. 30 (2005) 36-55.

[8] De Lanessan J.-L., Vanille, in: De Lanessan J-L. (Ed.), Les plantes utiles des colonies françaises, Impr. Natl., Paris, France, 1886, pp. 62-74.

[9] Roux P., Études morphologiques et anatomiques dans le genre Vanilla, in: Bouriquet G. (Ed.), Le vanillier et la vanille dans le monde, Lechevalier, Paris, France, 1954, pp. 44-92. 
[10] Odoux E., Escoute J., Verdeil J.-L., Brillouet J.-M., Localization of $\beta$-glucosidase activity and glucovanillin in vanilla bean (Vanilla planifolia Andrews), Ann. Bot. 92 (2003) 437-444.

[11] French J.C., Development of vanilla-bearing placental trichomes, in: Proc. Vanilla, First Int. Cong., Princeton, USA, Carol Stream, Allured Publ. Corp., USA, 2005, pp. 71-77.

[12] Ramaroson-Raonizafinimanana B., Gaydou E.M., Bombarda I., Long-chain $\gamma$-pyrones in epicuticular wax of two vanilla bean species: $V$. fragrans and $V$. tahitensis, J. Agric. Food Chem. 47 (1999) 3202-3205.

[13] Podstolski A., Havkin-Frenkel D., Malinowski J., Blount J.W., Kourteva G., Dixon R.A., Unusual 4-hydroxybenzaldehyde synthase activity from tissue cultures of the vanilla orchid Vanilla planifolia, Phytochem. 61 (2002) 611-620.

[14] Odoux E., Chauwin A., Brillouet J.-M., Purification and characterization of vanilla bean (Vanilla planifolia Andrews) $\beta$-D-glucosidase, J. Agric. Food Chem. 51 (2003) 3168-3173.

[15] Havkin-Frenkel D., Belanger F.C., Application of metabolic engineering to vanillin biosynthetic pathways in Vanilla planifolia, in: Verpoorte R. (Ed.), Applications of plant metabolic engineering, Springer, Germany, 2007, pp. 175-196.

[16] Pak F.E., Gropper S., Dai W.D., HavkinFrenkel D., Belanger F.C., Characterization of a multifunctional methyltransferase from the orchid Vanilla planifolia, Plant Cell Rep. 22 (2004) 959-966.

[17] Li H.M., Rotter D., Hartmann T.G., Pak F.E., Havkin-Frenkel D., Belanger F., Evolution of novel O-methyltransferases from the Vanilla planifolia caffeic acid O-methyltransferase, Plant Mol. Biol. 61 (2006) 537-552.

[18] Joel D.M., French J.C., Graft N., Kourteva G., Dixon R.A., Havkin-Frenkel D., A hairy tissue produces vanillin, Isr. J. Plant Sci. 51 (2003) 157-159.

[19] Arana F.E., Action of a $\beta$-glucosidase in the curing of vanilla, Food Res. 288 (1943) 343351.

[20] Jones M.A., Vicente G.C., Criteria for testing vanilla in relation to killing and curing methods, J. Agric. Res. 78 (1949) 425-434.

[21] Odoux E., Escoute J., Verdeil J.-L., The relation between glucovanillin, $\beta$-glucosidase activity and cellular compartmentation during the senescence, freezing and traditional curing of vanilla beans, Ann. Appl. Biol. 149 (2006) 43-52.

[22] Márquez O., Waliszewski K.N., The effect of thermal treatment on $\beta$-glucosidase inactivation in vanilla bean (Vanilla planifolia Andrews), Int. J. Food Sci. Technol. 43 (2008) 1993-1999.

[23] Siebert M., Sommer S., Li S.-M., Wang Z.-X., Severin K., Heide L., Genetic engineering of plant secondary metabolism. Accumulation of 4-hydroxybenzoate glucosides as a result of the expression of the bacterial ubiC gene in tobacco, Plant Physiol. 112 (1996) 811819.

[24] Flammarion C., Oléo-résine, in: Flammarion E. (Ed.), Dictionnaire encyclopédique universel, Lahure, Paris, France, 1902, pp. 49.

[25] Maestro Y., Bergia D., Lasserre C., Vanilla planifolia extract, method for obtaining same, and cosmetic or dermatological composition containing same, World Pat. WO 2007/ 034042 A2, 2007.

[26] Webb M.C., Williams E.G., The pollen tube pathway in the pistil of Lycopersicon peruvianum, Ann. Bot. 61 (1988) 414-423.

[27] Perez Silva A., Contribution à l'étude de la genèse des composés d'arôme au cours du procédé mexicain de transformation de la vanille (Vanilla planifolia Jackson), PhD Thesis, Univ. Montpellier II, France, 2006.

[28] Brundrett M.C., Kendrick B., Peterson C.A., Efficient lipid staining in plant material with Sudan Red 7B or Fluoral Yellow 088 in polyethylene glycol-glycerol, Biotech. Histochem. 66 (1991) 111-116.

[29] Odoux E., Changes in vanillin and glucovanillin concentrations during the various stages of the process traditionally used for curing Vanilla fragrans in Réunion, Fruits 55 (2000) 119-125.

[30] Huber D.J., Acidified phenol alters tomato cell wall pectin solubility and calcium content, Phytochem. 30 (1991) 2523-2527.

[31] Albersheim P., Nevins D.J., English P.D., Karr A., A method for the analysis of sugars in plant cell-wall polysaccharides by gas-liquid chromatography, Carbohydr. Res. 5 (1967) 340-345.

[32] Harris P.L., Henry R.L., Blakeney A.B., Stone B.A., An improved procedure for the methylation analysis of oligosaccharides and polysaccharides, Carbohydr. Res. 127 (1984) 59-73. 
[33] Blumenkrantz N., Asboe-Hansen G., New method for determination of uronic acids, Anal. Biochem. 54 (1973) 484-489.

[34] Brillouet J.-M., Williams P., Will F., Müller G., Pellerin P., Structural characterization of an apple juice arabinogalactan-protein which aggregates following enzymic dearabinosylation, Carbohydr. Polym. 29 (1996) $271-$ 275.

[35] Hakomori S.I., A rapid permethylation of glycolipids and polysaccharides catalysed by methyl sulfinyl carbanion in dimethyl sulfoxide, J. Biochem. (Tokyo) 55 (1964) 205-208.

[36] Pellerin P., Doco T., Vidal S., Williams P., Brillouet J.-M., O'Neill M.A., Structural characterization of red wine rhamnogalacturonan II, Carbohydr Res. 290 (1996) 183-197.

[37] Havkin-Frenkel D., Podstolski A., Vanillin production, US Patent US 2007/ 0044174 A1, 2007.

[38] Michodjehoun-Mestres L., Amraoui W., Brillouet J.-M., Isolation, characterization, and determination of 1-O-trans-cinnamoyl- $\beta-D-$ glucopyranose in the epidermis and flesh of developing cashew apple (Anacardium occidentale L.) and four of its genotypes, J. Agric. Food Chem. 57 (2009) 1377-1382.

[39] Mangin A., Les vanilliers, in: Mame A. \& sons (Eds.), Les plantes utiles, Tours, France, 1886, pp. 134-141.

[40] Angeles G., Berrio-Sierra J., Joseleau J.-P., Lorimier P., Lefèbvre A., Ruel K., Preparative laser capture microdissection and single-pot cell wall material preparation: a novel method for tissue-specific analysis, Planta 224 (2006) 228-232.

[41] Ishikawa H., Kuwano A., Matsumoto K., Complexation of vanillin and ethylvanillin with $\alpha-, \beta$-, and $\gamma$-cyclodextrin, J. Fac. Agric. Kyushu Univ. 52 (2007) 87-90.

[42] Sircar D., Mitra A., Evidence for $p$-hydroxybenzoate formation involving enzymatic phenylpropanoid side-chain cleavage in hairy roots of Daucus carota, J. Plant Physiol. 165 (2008) 407-414.

[43] Dalmer M., Ueber die Leitung der Pollenschlauche bei den Angiosperm, Jena Zeitsch. Naturwiss. 141 (1880) 530-566.

[44] Tilton V.R., Horner H.T., Stigma, style and obturator of Ornithogalum caudatum (Liliaceae) and their function in the reproductive process, Am. J. Bot. 67 (1980) 1113-1131.

[45] French J.C., Structure of ovular and placental trichomes of Araceae, Bot. Gaz. 148 (1987) 198-208.

[46] Fahn A., Shimony C., Glandular trichomes of Fragonia L. (Zygophyllaceae) species: structure, development and secreted materials, Ann. Bot. 77 (1996) 25-34.

[47] Simony R., Duquénoy P., Compléments à la connaissance anatomique et histochimique des fruits de vanilliers cultivés, en particulier dans les départements et territoires français d'outre-mer, Etudes O.-M 36 (1953) 129134.

[48] Katsuraya K., Okuyama K., Hatanaka K., Oshima R., Sato T., Matsuzaki K., Constitution of konjac glucomannan: chemical analysis and ${ }^{13} \mathrm{C}$ NMR spectroscopy, Carbohydr. Polym. 53 (2003) 183-189.

[49] Lord E.M., Adhesion and guidance in compatible pollination, J. Exp. Bot. 54 2003) 47-54.

[50] Mollet J.-C., Park S.-Y., Nothnagel E.A., Lord E.M., A lily stylar pectin is necessary for pollen tube adhesion to an in vitro stylar matrix, Plant Cell 12 (2000) 1737-1749.

[51] O'Neill M., Albersheim P., Darvill A.G., The pectic polysaccharides of primary cell walls, in: Dey P.M., Harborne J.B. (Eds.), Methods in plant biochemistry, Acad. Press, Newyork, USA, 1990, pp. 415-441.

[52] Funk C., Brodelius P.E., Phenylpropanoid metabolism in suspension cultures of Vanilla planifolia Andr., Plant Physiol. 94 (1990) 102-108. 


\begin{abstract}
Anatomía, histoquímica, y bioquímica de los sitios de acumulación de la glucovainillina, de una oleorresina, y de un mucílago en la vaina de vainilla verde madura (Vanilla planifolia, Orchidaceae): re-examen crítico de conjunto.
\end{abstract}

Resumen - Introducción. Las vainas de vainilla verdes maduras acumulan 4-O-(3-metoxibenzaldehído)- $\beta$-D-glucoside (glucovainillina), que, mediante hidrólisis con la ayuda de una $\beta$-glucosidasa endógena, libera vainillina, el mayor compuesto de aroma de la vainilla. Se mencionaron desde hace décadas de modo controvertido los sitios de almacenamiento de la glucovainillina en la vaina; mediante el empleo de una terminología técnica precisa y ampliamente aceptada, nos proponemos esclarecer dicha controversia presentando una tabla basada en pruebas anatómicas, histoquímicas y bioquímicas, de los sitios de acumulación de la glucovainillina. La vaina sintetiza asimismo una oleorresina y un mucílago de compuestos desconocidos; facilitamos aquí sus respectivas localizaciones y estructuras. Material y métodos. La anatomía de la vaina se examinó en microscopía fotónica y de epifluorescencia. Se puso en marcha un protocolo que permite una disección manual precisa de las diferentes partes anatómicas de la vaina (mesocarpio, placentae, tricomas, zona acelular intersticial del lóculo y semillas). Mientras que se extrajeron y analizaron la glucovainillina y los $\gamma$-pyranones mediante HPLC, las estructuras de los polisacáridos del mucílago se determinaron mediante permetilación. Resultados y discusión. La glucovainillina se almacena esencialmente en los placentae (92\%) y marginalmente en los tricomas (7\%); se detectaron rastros en el mesocarpio y el medio acelular intersticial del lóculo. Los tricomas acumulan cantidades masivas de una oleorresina fluorescente ( $44 \%$ ) y rica en alkenylmethyldihydro- $\gamma$-pyranones y sintetizan un mucílago constituido por un glucomanano y un polisacárido héctico de cadenas laterales monoméricas de arabinosa y de galactosa. Conclusión. Hasta el día de hoy permanecen desconocidos los papeles fisiológicos que desempeñan la glucovainillina, los pyranones de largas cadenas y el mucílago.

Francia / Vanilla planifolia / Orchidaceae / vainilla / tricomas / vanillina / oleoresinas / fluorescencia / mucilagos / polisacáridos 